\title{
Biyoçeşitliliğin Geliştirilmesi İçin Polinatör Böcekleri Çeken Bitki Türlerinin Kentsel Peyzajda Kullanımı: Kalecik Örneği
}

\author{
Hande ASLAN ${ }^{1 *}$ (i), Aysel USLU 2 (1) \\ ORCID 1: 0000-0002-2659-3604 \\ ORCID 2: 0000-0002-1158-7551 \\ ${ }^{1}$ Ankara Üniversitesi, Kalecik Meslek Yüksekokulu, Peyzaj ve Süs Bitkileri Yetiştiriciliği Programı, 06870, Ankara, Türkiye. \\ ${ }^{2}$ Ankara Üniversitesi, Ziraat Fakültesi, Peyzaj Mimarlı̆ı Bölümü, 06120, Ankara, Türkiye. \\ Öz \\ *e-mail: handeaslan@ankara.edu.tr \\ Giderek kentsel altyapının doğal yaşam alanlarının yerini almaya başladığı kentlerde, biyoçeşitliliğin azalması \\ başlıca sorunlardan biri olarak karşımıza çıkmaktadır. Bu çalışmada polinatörleri (tozlayıcılar) üzerine çekme \\ özelliğine sahip bazı doğal bitkilerle tasarım konusu üzerinde yoğunlaşmak istenmiş, özellikle Ankara kentsel \\ alanındaki tozlaştırıcı popülasyonunu dengeleyerek, biyoçeşitliliğin desteklenmesi çalışmalarında tercih \\ edilebilecek yerel türlerin ortaya konulması amaçlanmıştır. Kalecik ve çevresinin doğal bitki örtüsündeki türler \\ incelenerek, peyzaj tasarımlarında kullanılabilecek bitki türleri tespit edilmiştir. Bu türler arasından yurt dışında \\ tozlaşma bahçelerinde tercih edilen bitkiler listelenmiştir. Çalışma sonucunda, tozlaşmaya olumlu yöndeki \\ katkıları ile ön plana çıkan 10 cinse ait, 16 bitki türü belirlenmiş ve peyzaj tasarımlarında değerlendirilebilecek \\ çiçek (renk, çiçeklenme dönemi vb.), yaprak, yaşam formu ve boyu gibi özellikleri irdelenmiştir.
}

Anahtar Kelimeler: Biyoçeşitlilik, flora, Kalecik, polinatör, tozlaşma bahçeleri

\section{Use of Plant Species Attracting Polnators in Urban Landscape to Improve Biodiversity: Kalecik Sample}

\begin{abstract}
One of the main problems in the cities, urban infrastructure gradually replaces natural habitats, is biodiversity loss. In this study, it was aimed to focus on design with some natural plants and reveal the local plant species can be preferred in studies to support biodiversity by balancing the pollinator population especially in Ankara. By examining the species in the natural vegetation of Kalecik and its surroundings, plant species that can be used in landscape designs, were determined. Among these species, plants preferred in pollination gardens abroad were listed. As a result of the study, 16 plant species belonging to 10 genera, stand out with their positive contribution to pollination and can be preferred in urban landscape designs, were determined. Features which are prominent in landscape designs, such as flower (color, flowering period, etc.), leaves, life form and size, were examined.
\end{abstract}

Keywords: Biodiversity, flora, Kalecik, pollinator, pollination gardens

Atıf/Citation: Aslan, H, Uslu, A. (2021). Biyoçeşitliliğin Geliştirilmesi İçin Polinatör Böcekleri Çeken Bitki Türlerinin Kentsel Peyzajda Kullanımı: Kalecik Örneği. Journal of Architectural Sciences and Applications, 6 (1), 358-373. DOI: $10.30785 / \mathrm{mbud} .888300$ 


\section{Giriş}

Günümüzde dünya nüfusunun $\% 54$ 'ü kentlerde yaşamakta ve bu oranın 2050 yılı itibariyle $\% 66$ 'lara çıkacağı tahmin edilmektedir (UN-Habitat, 2016). Kentsel alanlar, yapısal ve fiziksel değişimlerin yoğun olarak yaşandığı mekânlar olup, artan nüfusa ve kentlerde yaşama talebine bağlı olarak farklı ölçek ve hızlarda genişlemektedir.

Biyoçeşitlilik alanında yapılan çalışmalar değerlendirildiğinde, genel olarak kentleşmenin biyoçeşitlilik üzerindeki olumsuz etkilerini konu alan çalışmaların fazla olduğu görülmektedir. Hâlbuki kentler, doğal kaynaklara erişim gibi nedenlerle, kuruluşları itibariyle biyoçeşitlilik açısından en zengin noktalara konumlandırılmış (uygun tarımsal peyzajlar, kıyısal alanlar ve akarsu sistemlerine sahip alanlar üzerine) olmalarına rağmen (Selim, Sever Mutlu ve Selim, 2015), arazi örtüsündeki değişimler, kentsel altyapının doğal yaşam alanlarının yerini almaya başlaması, doğal vejetasyon kaybı, habitat parçalanması gibi nedenlerle biyoçeşitliliği olumsuz yönde etkilemiştir ve etkilemeye devam etmektedir.

Bitki ve hayvan türleri, bu yeni ortamın beraberinde getirdiği zorluklara (doğal kaynakların kaybı (habitat ve besin), yüksek antropojenik baskı (yaya ve araç trafiği, endüstriyel gürültü gibi)), adaptasyon göstermekte güçlük çekmektedir. Doğal hayata uyum sağlamış canlılar, kentsel peyzajlara uyum sağlayamadığı durumlarda, kentsel ortamdan uzaklaşmak durumunda kalmaktadır (Lowry, Lill ve Wong, 2013).

Kentler, kentsel ısı adası etkisinin artması, yağış rejimlerindeki değişiklikler, kurak gün sayısının artması gibi iklim değişikliğinin neden olduğu etkilerin en yoğun hissedildiği alanlardır (Coşkun Hepcan, 2019). İklim değişikliğinin odağındaki kentlerde, biyoçeşitliliğin azalması başlıca sorunlardan biri olarak karşımıza çıkmaktadır. Özellikle kentsel ısı adası etkisinin artışı sonucunda, tür ölçeğinde yoğun soğuğu, sıcağı ve kuraklık stresini tolere edemeyen hassas türler artış göstermekte, tür fenolojilerinde değişiklikler görülmektedir. Örneğin değişen sıcaklıklara bağlı olarak, Ailanthus altissima (Mill.) Swingle bitkisinin artan sıcaklıklarla daha fazla büyüme gösterdiği belirlenmiştir (Selim, Sever Mutlu ve Selim, 2015). Ailanthus altissima bir istilacı yabancı türdür. İstilacı yabancı türler ekosistem dinamiklerini etkileyerek ekosistem işlevlerini değiştirme, doğal türlerin zenginlik ve bolluğunu azaltma, türler içinde genetik erozyona yol açma gibi etkilerle çok önemli ekolojik ve ekonomik kayıplara neden olabilmektedir (Xu ve diğerleri, 2012'den aktaran; Karaköse, Akbulut ve Bayramoğlu, 2018). Bitki türlerinin zenginliğinde meydana gelen azalma, tüm biyolojik çeşitliliği sınırlandırmakta olup, bu durum ekosistem istikrarının azalmasına yol açabilmektedir (Demir, 2009). Fukase ve Simons (2016), kentsel ortamda, ortam sıcaklıklarındaki değişimin, tozlayıcı nüfus üzerinde olumsuz etkileri olduğunu ifade etmektedir.

Dünya üzerinde her gün yaklaşık 140 bitki ve hayvan türünün yok olduğu tahmin edilmektedir (Özdemir ve Ulus, 2018). Dünyada 350.699 bitki türünün (The Plant List, 2021) 21.726'sı tehdit altındadır (IUCN, 2021). Bu tehditlerin 2000 yılında \%45 olan biyoçeşitlilik potansiyelini, 2030 yılında \%34- 42 arasında bir düzeye düşüreceği beklenmektedir (Alkemade ve diğerleri, 2009'dan aktaran; Eker, Vural ve Aslan, 2015).

Birçok bitki ve hayvan türünün yok olma tehlikesi ile karşı karşıya kalmasına paralel olarak, kentlerde yaban yaşamı için de yaşama ve beslenme ortamı oluşturacak yeşil alanların varsa korunması, tasarlanması, planlanması ve yönetimi çalışmaları çok önemlidir. Bu konuda özellikle yurt dışında tozlaşma bahçeleri adı altında örnekler görmek mümkündür. Örneğin, Smithsonian GardensPollinator Garden (Smithsonian Bahçeleri Tozlayıcı Bahçesi), yıl boyunca sinek, kuş, kelebek, arı gibi polinatörleri çekmek için çok çeşitli yerel bitkilerle düzenlenmiş bir bahçedir (Smithsonian Gardens, 2021) (Şekil 1). 


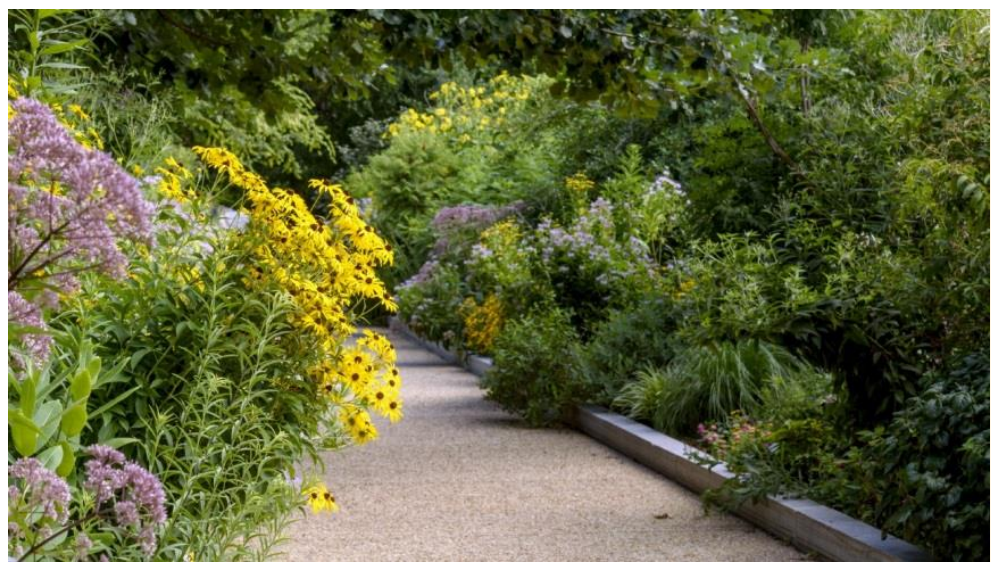

Şekil 1. Smithsonian Gardens Pollinator Garden (Smithsonian Bahçeleri Tozlayıcı bahçesi)- Washington, USA (Smithsonian Gardens, 2021)

Environmental Interpretive Center Pollinator Garden (Çevresel Yorumlama Merkezi Tozlayıcı Bahçesi) ise benzer şekilde, kelebekleri ve diğer polinatörleri kampüse çekmek için tasarlanmış bir bahçe olup, çeşitli nektarlı bitkileri ve farklı polinatör böcekler ve larvalar için yaşam ortamı sağlayan, aynı zamanda estetik değere sahip çok yıllık otsu bitkileri içermektedir (Şekil 2). Bu bitkilerden bazıları, Achillea spp., Allium spp., Carex spp., Hibiscus spp., Iris spp. Lobelia spp. türleridir (Environmental Interpretive Center, 2021).

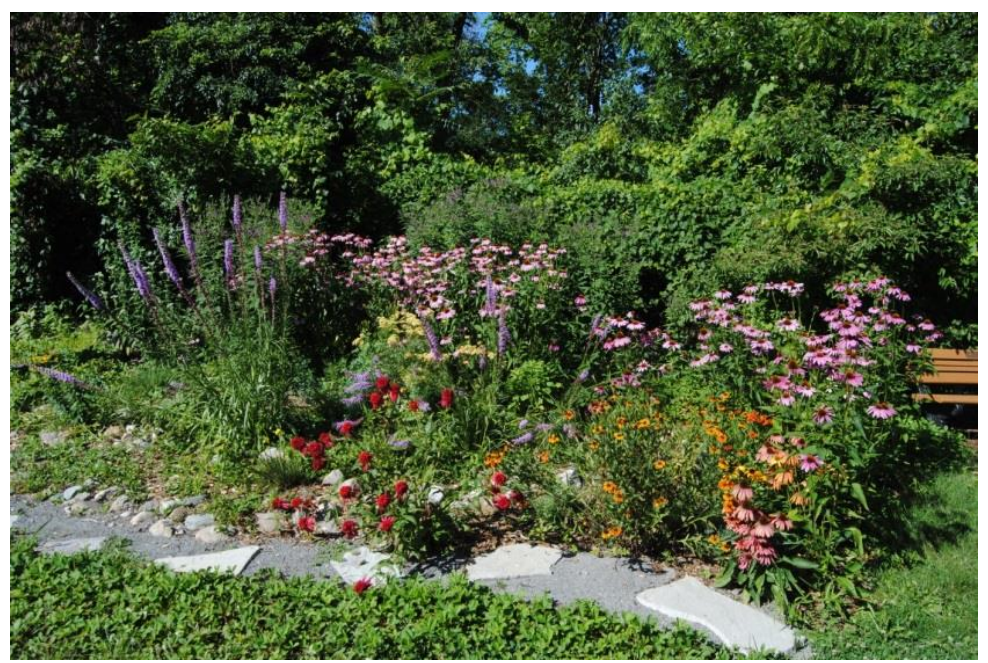

Şekil 2. Environmental Interpretive Center Pollinator Garden (Çevresel Yorumlama Merkezi Tozlayıcı Bahçesi)Dearborn, US (Environmental Interpretive Center, 2021)

Tozlaşma bahçeleri, arıları, kelebekleri, güveleri, sinek kuşlarını ve diğer faydalı canlıları çeken bahçeler olup tozlaştırıııların doğal yaşam alanlarının temsili bir örneğini oluşturmaktadır. Bu bahçeler, tozlaştırıcılar ve diğer yaban hayatı için barınma ve beslenme imkânı sunarak, popülasyonlarının artmasına, bu canlıların olumsuz kentsel koşullarda yaşamlarını devam ettirebilmelerine katkı sağlamaktadır (Özdemir ve Ulus, 2018). Böylece kentlerde hem bitki hem de hayvan türlerinin sayıca artışı mümkün olabilmektedir.

Buradan hareketle, tozlaşma bahçesi olarak tasarlanmış olsun ya da olmasın, yapılan tasarımlarda arıları, kelebekleri ve diğer tozlaştıııcı canlıları çeken bitkiler kullanılmalıdır. Bu gibi tasarımlarda, meyve etkisi, nektar etkisi gibi farklı özelliklerinden ötürü tercih edilebilecek bazı türler bulunmaktadır. Fakat bu türlerin de doğal bitki örtüsü içerisinden seçilmesi ayrıca önemlidir. Bu sayede, hem tozlaşmayı destekleyen türlerin kullanımı sağlanırken hem de bu türlerin yerel bitkiler oluşu ile kentin ekolojik koşullarına iyi adapte olmuş, çevresel etkilere (özellikle iklim değişikliğinin etkilerine) karşı daha dayanıklı, daha az bakım isteyen türler kullanılmış olunabilecektir.

Tüm bu bahsedilenler ışığında, biyoçeşitliliğin desteklenmesinde özellikle kent ekolojisi ile uyumlu, polinatörleri üzerine çekerek tozlaşmaya yardımcı olan bazı bitki türlerinin belirlenmesi önemlidir. 
Türlerin tercihen kentin doğal bitki örtüsünde bulunan yerel bitkiler olmaları, daha başarılı uygulamalara imkân tanıyabilecektir.

Bu çalışmada polinatörleri (tozlayıcılar) üzerine çekme özelliğine sahip bazı doğal bitkilerle tasarım konusu üzerinde yoğunlaşmak istenmiş, özellikle Ankara kentsel alanındaki tozlaştırıcı popülasyonunu dengeleyerek, biyoçeşitliliğin desteklenmesi çalışmalarında tercih edilebilecek yerel türlerin ortaya konulması amaçlanmıştır. Kalecik ve çevresinin florasını konu alan makale ve tezler incelenerek çalışma alanının doğal bitki örtüsü listelenmiştir. Literatür araştırmaları sonucunda elde edilen bu liste içerisinden estetik özellikleriyle kent peyzajına değer katabilecek olan ve tozlaştırıcı böcekleri üzerine çekme potansiyeline sahip bitkiler tespit edilmiştir. Bu türlerin peyzaj tasarımlarında değerlendirilebilecek özelliklerinin ortaya konulması amacıyla, literatür taranmış, alanında yapılmış çalışmalar değerlendirmeye alınarak, çiçek (renk, çiçeklenme dönemi vb.), yaprak, yaşam formu, boyu ve habitatı gibi bazı özellikleri irdelenmiştir.

\subsection{Kentsel Biyoçeşitliliğin Desteklenmesinde Tozlaşma ve Doğal Bitki Türlerinin Rolü}

Biyoçeşitlilik, genetik çeşitlilik (belirli türler içindeki çeşitlilik), tür çeşitliliği (farklı türler arasındaki çeşitlilik) ve ekosistem çeşitliliğini (dünyadaki farklı ekosistemler arasında ve içindeki habitat, tür çeşitliliğini) kapsayan geniş bir kavramdır. Biyoçeşitlilik, farklı habitatlarda yaşayan; kuşlar, memeliler, böcekler, bitkiler, mikroplar gibi tüm canlı organizmaların bir çeşitliliğidir (Uslu ve Shakouri, 2013).

Biyoçeşitliliğin önemli bir bileşeni olan bitkiler; havayı temizleme, toprağa organik madde kazandırma, erozyonu önleme gibi işlevlerinin yanı sıra diğer canlılara barınma ve beslenme ortamı sunarak ekosistemin sürekliliğini sağlarlar.

İnsan ve diğer canlıların yaşamının devamlılığı için bitkiler, bitkilerin devamlılı̆̆ için de tozlaşma oldukça önemlidir. Bitkilerin tozlaşabilmesi için su ve rüzgâr gibi cansız etmenlere ya da böcekler, kuşlar, yarasalar gibi diğer canlı tozlaşma vektörlerine ihtiyaçları vardır (Silici, 2005). Arılar, karıncalar, kelebekler, sinekler, kınkanatılıar ile bazı kuşlar ve memeliler tozlaşmada etkili organizmalardır (Bağrıaçık, 2017). Polinatör olarak isimlendirilen tozlaşma sağlayan bu canlılar içinde, en etkili ve başarılı tozlaşmanın böceklerle yapıldığı bilinmektedir. Özellikle yararlı böcekler olarak bilinen arıların çiçekli bitkilerin polinasyonuna sağladıkları katkılar göz ardı edilemez düzeydedir (Gösterit ve Güler, 2005). Bal arıları çiçekli bitkilerin \% 80'inde tozlaşmayı gerçekleştirmektedir (Özbek, 2003). Polinatörler, bitkilerin tozlaşmasında aktif rol alarak tohum ve meyve oluşumuna katkıda bulunmakta, bitkilerin ekosistem içerisindeki sürekliliklerini ve çeşitliliklerini sağlamaktadırlar (Özbek, 2010). Lowenstein, Matteson ve Minor (2015) yaptıkları çalışmada, polinatör ziyaretçilerin artışına bağlı olarak, meyve ve tohum tutumunun arttığını, özellikle farklı bitki türlerini barındıran alanların polinizasyonu artırdığını belirtmiştir.

Genellikle polen aktarımı ileri düzeyde yapılmış bir çiçek, çimlenme kapasitesi daha yüksek olan tohumlar taşıyan meyve bağlamakta, çiçeklenme ve meyve oluşumu arasındaki sürenin düşmesiyle meyvenin hastalıklara ve zararlı böceklere maruz kalma tehlikesi azalmakta, ayrıca su tasarrufu sağlanmakta ve pestisit kullanımının azalmasına katkıda bulunulmaktadır (Polat, Özüiçli, Çetin, ve Aydın, 2020). Tüm bunların, kentsel ekosistemlerin sürdürülebilirliği ve biyoçeşitlilik açısından önemi büyüktür.

Ancak kentlerde daha önce de bahsi geçen kentleşme, küresel ısınma ve diğer antropojenik etkiler, bitki ve hayvan türlerinin sayısında azalmalara neden olmaktadır. Bennett ve Lovell (2019), kentsel alanlarda farklı arazi örtüsü değişkenlerinin kentsel tarım alanlarındaki polinatörleri nasıl etkilediğini araştırdıkları çalışmalarında, arıların sayıca fazlalıklarının ve vücut büyüklüklerinin peyzajlara ve yerel ölçeğe göre değiştiğini, geçirimsiz yüzeylerin artışına bağlı olarak polinatörlerin sayısının azaldığını ortaya koymuştur. Özellikle polinatör böceklerin çeşitliliği ve yoğunluğundaki azalma, bitki çeşitliliği ve yoğunluğundaki azalmayı da beraberinde getirmektedir. Öyle ki, belirli bir polinatör böcekle tozlaşan bitkilerde polinatörün yok olması, bitkinin yok olması anlamına gelebilmektedir (Bağrıaçık, 2017).

Küresel iklim değişikliği ile mücadele veya kentsel biyoçeşitliliğin desteklenmesine yönelik çalışmalar kapsamında, özellikle ekolojik süreçler ile uyumlu, doğaya saygılı, sürdürülebilir plan kararları 
alınması ve tasarımlar uygulanması konusundaki farkındalık artırılmalıdır. Kentler için yeşil altyapı stratejilerinin geliştirilerek, ekosistem servislerinden yararlanılması hedeflenmelidir. Bu açık yeşil alan sistemleri planlanırken, kentsel peyzajlarda polinatörleri üzerine çekerek tozlaşmaya yardımcı olan doğal bitki örtüsündeki bitki türlerine yer verilmesi daha da önemli bir hal almaktadır. Günümüzde kentsel peyzajlarda özellikle egzotik türlerin kullanımına yönelik bir talep söz konusudur. Hâlbuki bazı egzotik türler, istilacı olabilmekte, yerli bitki türleri üzerinde baskı oluşturarak biyoçeşitliliğe olumsuz yönde etki edebilmektedir. Tozlaştırıcıların, yerel yetişme mevsimi, iklim ve toprak faktörlerine iyi adapte olmuş doğal bitkilerle evrimleştiği bilinmektedir (Özdemir ve Ulus, 2018). Fukase ve Simons (2016), bitki fenolojisinin çevresel koşullardaki değişimlerden etkilendiğini ve yerli bitki türlerinin bulunduğu alanların, yerli olmayan bitki türlerinin bulunduğu alanlara nazaran, polinatörlere daha kesintisiz kaynaklar sağladığını belirtmiştir.

Pek çok çalışma, kentsel alanlarda biyoçeşitliliğin artırılması amacıyla, özellikle çiçekli doğal bitki türlerinin kullanımını önermektedir. Bennet ve Lovell (2019), kentsel alanlarda özellikle arı türleri için barınma ve beslenme imkânı sunan çiçekli bitkilerin kullanımının gerekliliğini vurgulamış; Wenzel, Grass, Belavadi ve Tscharntke (2019) ise, kentsel yeşil alan miktarının ve çiçekli bitki sayısının artması ile polinatörler için barınma imkânının artmasına bağlı olarak, kentlerde polinatör sayısının artabildiğini ifade etmiştir.

Kentsel açık yeşil alanların miktarları artırıııken, bu çalışma kapsamında önerildiği gibi, polinatörleri üzerine çekme etkisine sahip bazı doğal türlerin kullanımı ile de yeşil alanların nitelikleri de artırılabilecektir. O halde şu aşamada, kentlerde doğal bitki örtüsündeki türlerin kullanımının önemini kısaca açıklamak yerinde olacaktır.

-Doğal bitki türleri, bulundukları yörenin ekolojisine uyum sağlamış bitkiler olduklarından, değişen çevre koşullarına daha iyi adapte olurlar.

-Yabancı (egzotik) türlere nazaran daha dayanıklı bitkilerdir. Özellikle iklim değişikliğinin beraberinde getirdiği ekstrem sıcaklıklar, kuraklık ya da yağıs rejimindeki düzensizlikleri daha iyi tolere edebilirler.

-Yaban yaşamını destekleyen ortamları barındırırlar (Uslu ve Shakouri, 2013).

-Doğal bitki türleri kentsel ve kırsal alanlar arasındaki ekosistem bütünlüğünü sağlarlar.

Araştırmacıların kentsel alanlardaki doğal kuş türleri üzerine yaptıkları araştırmalar da bu canlıların varlığının o alandaki doğal vejetasyona bağlı olduğunu göstermektedir (Deniz ve Şirin, 2005).

-Daha az bakım isterler. Bu açıdan egzotik türlerle yapılan düzenlemelere göre daha düşük maliyetlidirler.

-Daha az bakım, sürdürülebilirliğe katkı sağlar. Daha az bakım, daha az oranda su, gübre ve kimyasal demektir.

Maalesef ki yaygın görüş, peyzaj alanlarının özellikle de parklarda düzenli biçme, ilaçlama, sulama yapılmadığında estetik olamayacağı ve bakımsız duracağı yönündedir. Aynı yanlış kanıyla peyzajlar, süs bitkileri ile donatılmış alanlar olmalıdır. Ancak biyoçeşitlilik, farklı türlerin kullanımı ile zenginleştirilmiş alanlar yaratıldığında desteklenebilmektedir ve doğal türlerle zenginleştirilen tasarımlar az bakım istemektedir.

- Doğal bitki türleri hastalıklara karşı da daha dayanıklıdırlar. Bu, daha az ilaçlama anlamına gelir. ilaçlama biyolojik çeşitliliği olumsuz etkileyen bir unsurdur.

\section{Materyal ve Yöntem}

Kalecik illçesi, Ankara il Merkezi'nin kuzey doğusunda yer almakta olup denizden yüksekliği ortalama 725 metredir (Şekil 3). Yörede tipik karasal iklim özellikleri görülmekle birlikte Kalecik'in kendine özgü bir iklim yapısı vardır. 2000 m yükseklikteki İdris dağı ile 500 m yükseklikteki Kızılırmak vadi çukuru arasında yerleşmiş olan Kalecik'te mikroklima iklim karakteri görülmektedir (Akça, Türkmen, Taşkın, Soba ve Öztürk, 2015). 


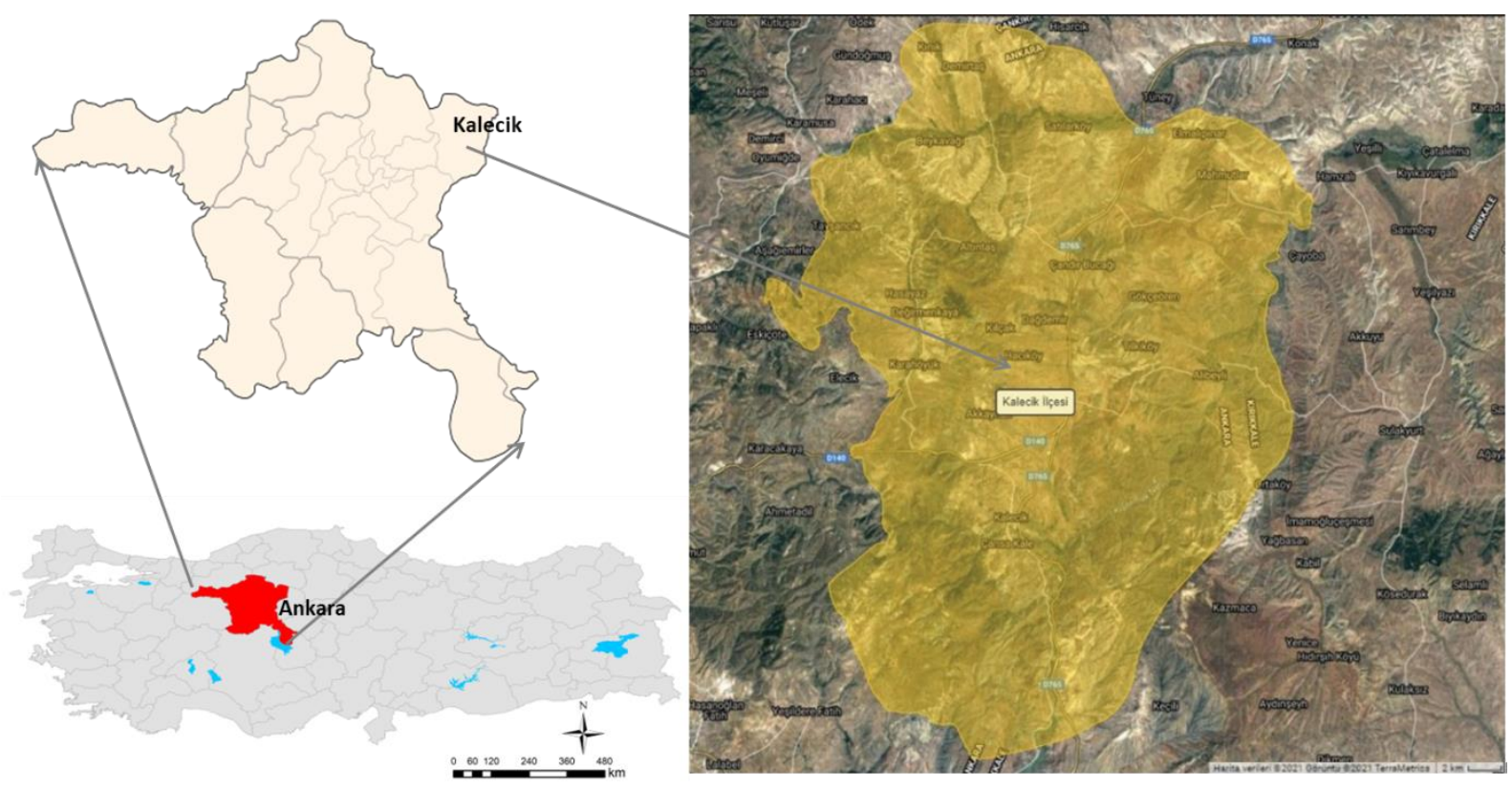

Şekil 3. Çalışma alanının konumu

Ankara kent koşullarında peyzaj tasarımlarında kullanılabilecek tozlaşmaya yardımcı olası yerel bitki türlerinin belirlenebilmesi için yapılmış olan bu derleme literatür çalışmasında, Ankara ili Kalecik ilçesinin doğal bitki örtüsü değerlendirmeye alınmıştır. Öncelikle, Kalecik ilıçesi doğal bitki örtüsünün belirlenmesine yönelik olarak, Kalecik ve çevresinin florasını konu edinen makale ve tezler taranmıştır. Bu çalışmalar arasında, Varol ve Aydoğdu (1999)'nun Akyurt - Kalecik arasında kalan step florasını inceledikleri çalışma ile Doğar (2019)'ın Ankara Üniversitesi Kalecik Bağcııık Araştırma ve Uygulama İstasyonu florasını da içeren tez çalışmaları esas alınmıştır.

Bu flora çalışmalarının birlikte değerlendirilmesi ile iki ayrı çalışmada yer alan ortak türler dışında farklılık gösteren türlerin de tespit edilmesi sağlanmış, böylece daha geniş bir alanı kapsayacak şekilde yeni bir bitki listesi elde edilmiştir. Elde edilen yeni bitki listesi, Eker, Vural ve Aslan (2015)'ın Ankara geneli için hazırladıkları; 'Ankara ili genel flora listesi' ile karşılaştırılarak güncel veriler elde edilmiştir. Bahsi geçen arazi ve literatür çalışmalarına dayanarak, çalışma alanında var olduğu bilinen endemik bitkilerin IUCN (International Union for Conservation of Nature: Uluslararası Doğa Koruma Birliği) tehlike kategorilerinin belirlenmesi için yine Eker, Vural ve Aslan (2015)'ın güncellemiş olduğu tehlike kategorileri değerlendirmeye alınmıştır.

Bir sonraki aşamada ise, yapılan bu değerlendirme süreci sonucunda elde edilen bitki listesi içerisinden, estetik özellikleriyle kent peyzajına görsel açıdan yüksek değer katabilecek ve peyzaj tasarımlarında çiçek, yaprak, boyut, yaşam formu gibi özelliklerinden yararlanılarak ön plana çıkabilecek doğal bitkilerin seçimi yapılmıştır. Böylece Kalecik florası içerisinde estetik özellikleri ile öne çıkan bitkilerin belirlenmesi sağlanmıştır.

Bu bitkiler arasında varsa tozlaşmaya olumlu yönde katkı sağlayan bitkilerin analiz edilebilmesi için; Garbuzov ve Ratnieks (2014) 'in "Listmania: The Strengths and Weaknesses of Lists of Garden Plants to Help Pollinators (Polinatörlere Yardım Eden Bahçe Bitkileri Listelerinin Güçlü ve Zayıf Yanları)' başlıklı çalışmaları esas alınmıştır. Garbuzov ve Ratnieks (2014), yurt dışında tozlaşmaya yardımcı bitkilerin listelendiği çalışmaları inceleyerek listelerin çoğunda ortaklık gösteren cinsleri saptamışlardır. Bu sayede, farklı birçok çalışma ile tozlaşmaya olumlu yöndeki mutlak katkıları ortaya konulmuş olan 38 cins belirlemişlerdir. Bahsi geçen çalışmada listelenen 38 cins, daha önce Kalecik için elde edilen, peyzaj tasarımlarında kullanılabilecek bitkiler arasında aranmıştır. Böylece Kalecik doğal bitki örtüsünde bulunan, özellikle Ankara kentsel alanındaki peyzaj tasarımlarında kullanılabilecek ayrıca tozlaştırıcı canlı popülasyonunu dengeleyerek, biyoçeşitliliği desteklemesi beklenen bitki türleri belirlenmiştir.

Bu türlerin peyzaj tasarımlarında değerlendirilebilecek özelliklerinin ortaya konulması amacıyla, çiçek özellikleri (renk, çiçeklenme dönemi vb.), yaprak özellikleri (varsa etli yaprak, aromatik koku vb.), 
yaşam formu, ulaşabileceği boy ve habitat özellikleri irdelenmiştir. Literatürde alanında yapılmış çalışmalar değerlendirmeye alınarak, bitkilerin habitat özellikleri ve ulaşabileceği boylar belirlenmiş̧ir. Kimi taksonların habitatları TÜBIVES (Türkiye Bitkileri Veri Servisi) üzerinden araştırılmıştır. Bitkilerin ulaşabileceği boylar, literatür taramaları sonucunda elde edilen verilere bağlı olarak ortalama değerler şeklinde ifade edilmiştir. Çiçek rengi, çiçek kokusu, aromatik yapraklara sahip oluşu, etli yaprak yapısı, meyve şekli ve rengi gibi diğer morfolojik özelliklerinin yorumlanması sonucunda ise bitkilerin estetik özellikleri ortaya konmuştur.

Tüm bu araştırmalar ve değerlendirmeler sonucunda elde edilmiş olan, türlerin peyzaj tasarımlarında göz önünde bulundurulması gereken bazı özellikleri (habitatı, yaşam formu, boyu, çiçeklenme dönemi, estetik özelliği) ile ilgili veriler, Araştırma Bulguları kısmında detaylandırılmıştır.

\section{Araştırma Bulguları}

Kalecik ve yakın çevresinin florasını konu alan çalışmalara dayalı literatür araştırmaları sonucunda; peyzaj mimarlığı çalışmalarında süs bitkisi olarak değerlendirilebilecek, 52'si endemik olmak üzere 87 adet takson belirlenmiştir. Bu bitkiler arasında, Garbuzov ve Ratnieks (2014)'in listesinde yer alan, çeşitli çalışmalarla polinatörleri üzerine çektiği ortaya konmuş olan cinslere ait türler arandığında, 4'ü endemik olmak üzere toplamda 16 adet bitki türü belirlenmiştir (Çizelge 1).

Çizelge 1. Polinatör çekme özelliği ile ön plana çıkan Kalecik doğal bitki örtüsündeki türler

\begin{tabular}{|c|c|c|c|c|}
\hline NO & FAMILYA & LATINCE ADI & $\begin{array}{l}\text { TÜRKÇE ADI } \\
\text { (Eker, Vural ve Aslan, } \\
\text { 2015) }\end{array}$ & $\begin{array}{l}\text { ENDEMIZM } \\
\text { DERECESi } \\
\text { (Eker, Vural ve } \\
\text { Aslan, 2015) } \\
\end{array}$ \\
\hline 1 & Amaryllidaceae & Allium atroviolaceum Boiss. & Lifli körmen & \\
\hline 2 & Amaryllidaceae & $\begin{array}{l}\text { **Allium huber-morathii Kollmann, Özhatay } \\
\text { \& Koyuncu }\end{array}$ & Narin soğan & LC \\
\hline 3 & Caryophyllaceae & **Dianthus lydus Boiss. & Kan karanfil & LC \\
\hline 4 & Compositae & ${ }^{* *}$ Achillea teretifolia Willd. & Beyaz civanperçemi & LC \\
\hline 5 & Crassulaceae & Sedum acre L. subsp. acre & Acı damkoruğu & \\
\hline 6 & Crassulaceae & Sedum album L. & Çoban kavurgası & \\
\hline 7 & Crassulaceae & Sedum subulatum (C.A.Mey.) Boiss. & Kedi tırnağı & \\
\hline 8 & Geraniaceae & Geranium pyrenaicum Burm.f. & Gelin çarşafı & \\
\hline 9 & Geraniaceae & Geranium tuberosum L. & Çakmuz & \\
\hline 10 & Rosaceae & Cotoneaster nummularius Fisch. \& C.A.Mey. & Dağ muşmulası & \\
\hline 11 & Rosaceae & Crataegus monogyna Jacq. var. monogyna & Yemişen & \\
\hline 12 & Rosaceae & Prunus divaricata Ledeb. var. divaricata & Yunus eriği & \\
\hline 13 & Rosaceae & Prunus spinosa L. & Çakal eriği & \\
\hline 14 & Caprifoliaceae & Lonicera caucasica Pall. & Çakkana & \\
\hline 15 & Lamiaceae & **Thymus leucostomus Hausskn. \& Velen. & Ana kekik & VU \\
\hline 16 & Lamiaceae & Thymus sipyleus Boiss. & Sipil kekiği & \\
\hline
\end{tabular}

Çizelge 1'de verilen, Allium, Dianthus, Achillea, Sedum, Geranium, Cotoneaster, Crataegus, Prunus, Lonicera ve Thymus cinslerine ait taksonların, tozlayıcı canlılar üzerindeki etkilerinin ortaya konulduğu çalışmalar mevcuttur. Örneğin, Genç İlçesi (Bingöl-Merkez) ve çevresinde doğal alanlarda yayılışı olan ve arılarca en fazla ziyaret edilen bitki taksonlarının araştırıldığı çalışmada, 78 takson listelenmiştir. Bu liste içerisinde, Achillea, Thymus, Crataegus, Dianthus ve Geranium cinsine ait taksonlar da yer almakta olup, bu bitkilerin bahsi geçen çalışma alanında arılarca en fazla ziyaret edilen bitkiler arasında olduğu anlaşılmaktadır (Demirpolat ve Kılıç, 2019).

Thymus spp. türlerinin uçucu yağlar bakımından zengin olan çiçeklerinin, özellikle arılar tarafından ziyaret edildiği yine çalışmalarla ortaya konmuştur. Kekik türleri, çiçeklenme dönemlerinde arılar için 
iyi bir nektar ve polen kaynağı olup, Apis mellifera ve Bombus terrestris türü arılar için oldukça caziptir (Campolo, Zappala, Malacrino, Laudani ve Palmeri, 2015).

Bir diğer çalışma, yeşil çatı karakteristiklerinin polinatör topluluğu üzerindeki etkilerinin araştırıldığı tez çalışmasıdır. Grimshaw- Surette (2020), farklı bitki türü zenginliğine sahip yeşil çatılarda polinatör ziyaretlerini incelemiş, en büyük ikinci tozlayıcı sayısının, Sedum cinsine ait bitki türlerini ziyaret ettiğini tespit etmiştir.

Benzer şekilde, Maclvor, Ruttan ve Salehi (2015) yaptıkları çalışmada, yeşil çatıyı ziyaret eden arılar üzerinde incelemelerde bulunmuş, arıların yuvalarına taşıdıkları polenlerin $\% 80,5$ 'inin Sedum spp. türlerine ait olduğunu tespit etmişlerdir. Araştırmacılar, Sedum spp. türlerinin özellikle Halictus rubicundus (tel arısı), Apis melifera L. (bal arısı), Megachile rotundata F. (yaprak kesici arı) gibi egzotik arı türleri için çok cazip ve çekici bitkiler olduğunu, kentlerde yeşil çatı uygulamalarında bu bitkilerin kullanımının yaygınlaştırıması ile kentlerde arı popülasyonunun artmasına önemli katkı sağlanabileceğini ifade etmiştir.

Polinatör çekme özelliği ile ön plana çıkan Kalecik doğal bitki örtüsündeki türlerin başlıcaları, Sedum spp., Prunus spp., Thymus spp. ve Allium spp.'dir. Çizelge 1'de görüleceği üzere Rosaceae falmilyası, 3 cinse ait 4 tür ile en fazla tür sayısına sahip olan familyadır.

Allium huber-morathi (narin soğan), Dianthus lydus (kan karanfil), Achillea teretifolia (beyaz civanperçemi) ve Thymus leucostomus (ana kekik) estetik çiçekleri ile ön plana çıkan bitkiler olmalarının yanı sıra, endemik bitkiler olmaları ile de önemlidir (Şekil 4).

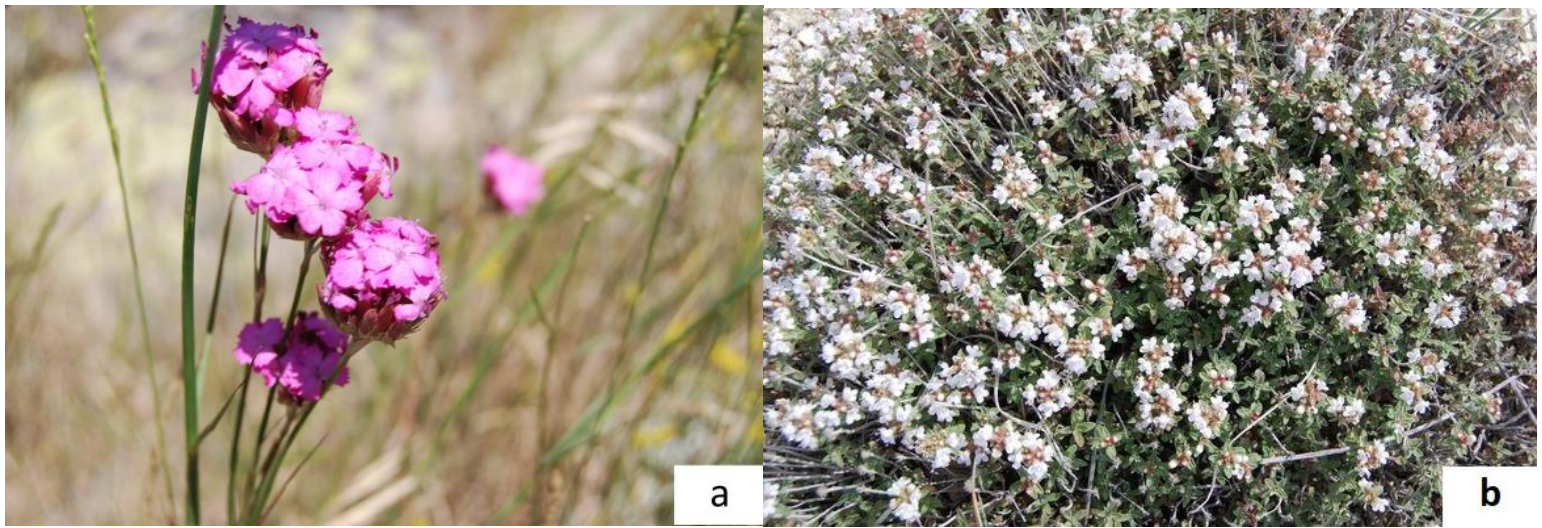

Şekil 4. a. Dianthus lydus (Yılmaz, 2011) ve b. Thymus leucostomus (Yılmaz, 2008a)

Liste incelendiğinde, Kalecik ve çevresinin doğal bitki örtüsünde bulunup polinatör çekme potansiyeline sahip olan bitkilerin yaşam formlarının, çok yıllık otsu, soğanlı/yumrulu, sukulent, çalı veya küçük ağaç formunda olduğu görülmektedir. Sedum acre subsp. acre (Acı damkoruğu) ve Sedum album (Çoban kavurgası) sukulent bitki olup (Şekil 5), Thymus sipyleus (Sipil kekiği) otsu karakterdeki bitkilere, Geranium tuberosum (Çakmuz) ise yumrulu bitkilere örnek olarak verilebilir (Şekil 6). Cotoneaster nummularia (Dağ muşmulası) çalı, Prunus divaricata var. divaricata (Yunus eriği) ise küçük ağaç özelliğindedir (Şekil 7).

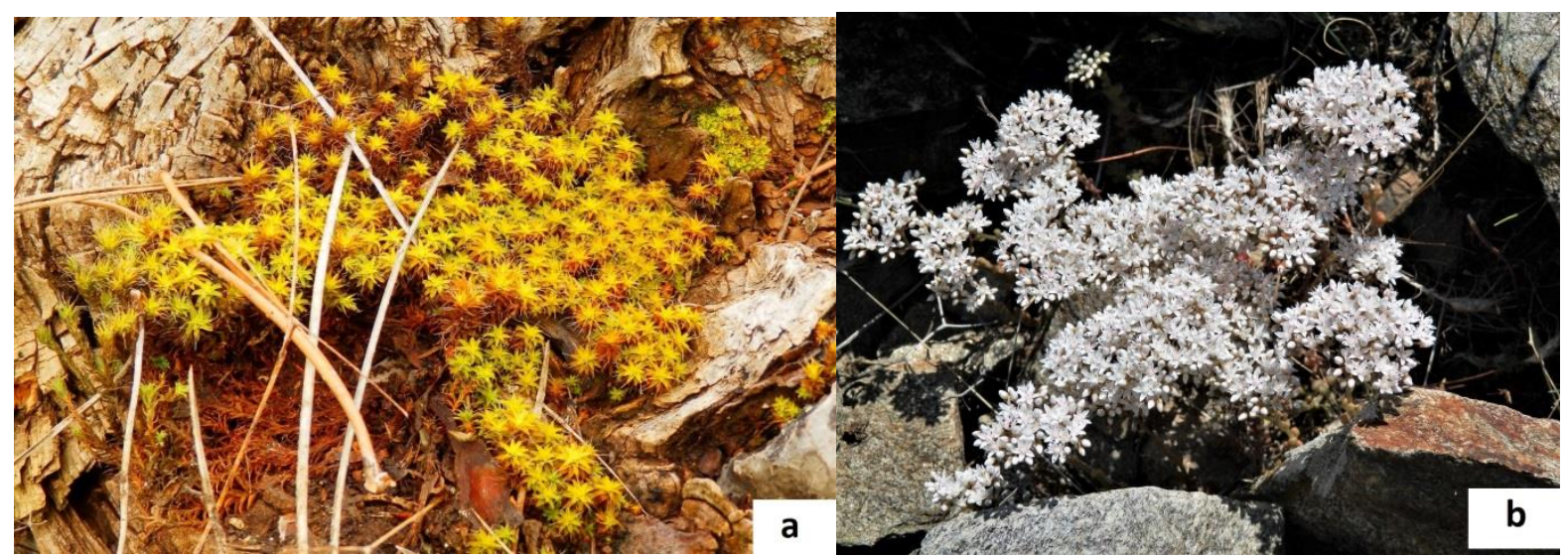

Şekil 5. a. Sedum acre subsp. acre (Demir, 2018) ve b. Sedum album (Demir, 2019) 


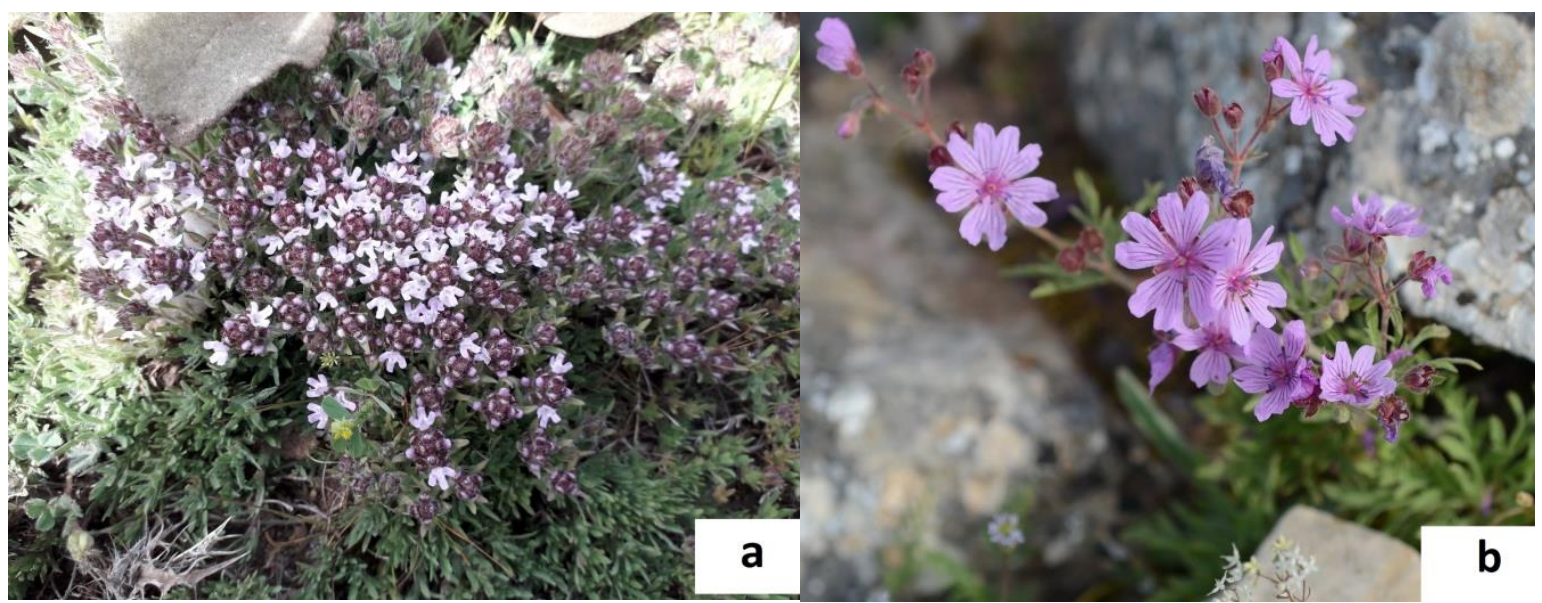

Şekil 6. a. Thymus sipyleus (Yılmaz, 2019) ve b. Geranium tuberosum (Yılmaz, 2019)

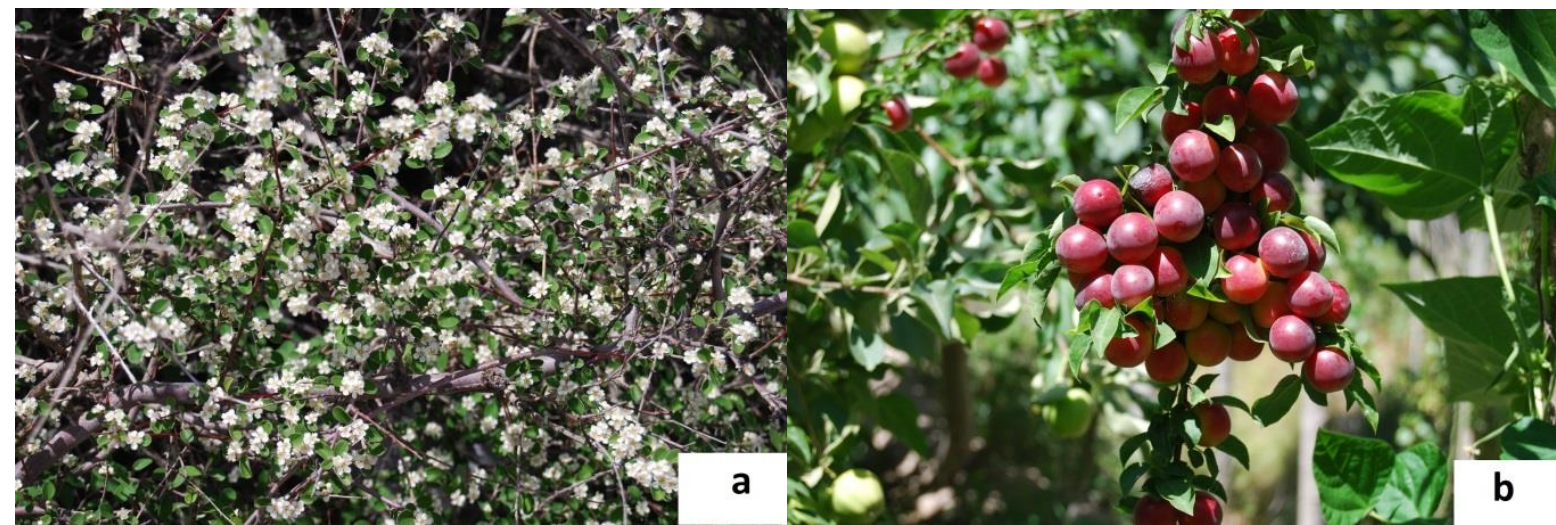

Şekil 7. a. Cotoneaster nummularia (Yılmaz, 2008a) ve b. Prunus divaricata var. divaricata (Yılmaz, 2008c)

Bitkilerin habitat, form, boy ve yaşam formu, estetik özellikleri gibi özelliklerinin bilinmesi ve birlikte değerlendirilmesi ile bu bitkilerin peyzaj çalışmalarında uygun kullanım şekilleri belirlenebilecektir.

Bitkilerin habitat özellikleri, boyu gibi verilerin elde edilebilmesi için, alanında yapılan çalışmaların incelendiği literatür araştırmaları sonucunda, taksonların peyzaj tasarımlarında göz önünde bulundurulması gereken bazı özellikleri derlenmiş ve bu özellikler Çizelge 2'de verilmiştir.

Çizelge 2. Polinatör çekme özelliği ile ön plana çıkan Kalecik doğal bitki örtüsündeki türlerin, peyzaj tasarımlarında göz önünde bulundurulması gereken bazı özellikleri

\begin{tabular}{|c|c|c|c|c|c|c|}
\hline NO & LATINCE ADI & НАВітATI & $\begin{array}{l}\text { YAŞAM } \\
\text { FORMU }\end{array}$ & BOYU & $\begin{array}{l}\text { ÇIÇEKLENME } \\
\text { DÖNEMi }\end{array}$ & ESTETiK ÖZELLiĞi \\
\hline 1 & Allium atroviolaceum & $\begin{array}{l}\text { Ekili tarla, bağlar, kırlar ve orman } \\
\text { kenarları, çayırlıklar, nadas } \\
\text { tarlaları (TÜBiVES, 2021) }\end{array}$ & Soğanlı & $50-100 \mathrm{~cm}$ & $\begin{array}{l}\text { Haziran- } \\
\text { Temmuz }\end{array}$ & Mor çiçek \\
\hline 2 & Allium huber-morathii & $\begin{array}{l}\text { Meşe ve karaçam ormanları, } \\
\text { çalılıklar, taşlı yamaçlar(TÜBiVES, } \\
\text { 2021) }\end{array}$ & Soğanlı & $10-25 \mathrm{~cm}$ & $\begin{array}{l}\text { Haziran- } \\
\text { Temmuz }\end{array}$ & Mor çiçek \\
\hline 3 & Dianthus lydus & $\begin{array}{l}\text { Taşlık açık alanlar ve yamaçlar, } \\
\text { meşe ve çam ormanı altları } \\
\text { (Bağçıvan, 2014) }\end{array}$ & $\begin{array}{l}\text { Çok yıllık } \\
\text { otsu }\end{array}$ & $25-60 \mathrm{~cm}$ & $\begin{array}{l}\text { Haziran- } \\
\text { Temmuz }\end{array}$ & Pembe çiçek \\
\hline
\end{tabular}


Bozkır, kayalık yamaçlar, iğne

$4 \quad$ Achillea teretifolia

5 Sedum acre subsp. acre
yapraklı ormanları, subalpin çayırları (TÜBIVES, 2021) Taşlık kayalık alanlarda, 800-2000 $\mathrm{m}$ yüksekliklerde

$\begin{array}{lll}\begin{array}{l}\text { Çok yıllık } \\ \text { otsu }\end{array} & 20-35 \mathrm{~cm} & \begin{array}{l}\text { Haziran- } \\ \text { Eylül }\end{array}\end{array}$

西

Sukulent, $\quad 5-15 \mathrm{~cm} \quad$ Haz

Haziran- Sarı çiçek, etli

Ağustos yaprak yapısı

\begin{tabular}{|c|c|c|c|c|c|c|}
\hline 6 & Sedum album & $\begin{array}{l}\text { Duvarlar, kayalık yamaçlar ve } \\
\text { yarıklar (TÜBiVES, 2021) }\end{array}$ & Sukulent & $5-15 \mathrm{~cm}$ & $\begin{array}{l}\text { Haziran- } \\
\text { Eylül }\end{array}$ & $\begin{array}{l}\text { Beyaz çiçek, etli } \\
\text { yaprak yapısı }\end{array}$ \\
\hline 7 & Sedum subulatum. & $\begin{array}{l}\text { Kayalık yamaçlar, uçurumlar } \\
\text { (TÜBiVES, 2021) }\end{array}$ & Sukulent & $5-20 \mathrm{~cm}$ & $\begin{array}{l}\text { Haziran- } \\
\text { Ağustos } \\
\end{array}$ & $\begin{array}{l}\text { Sarı çiçek, etli } \\
\text { yaprak yapısı }\end{array}$ \\
\hline 8 & Geranium pyrenaicum & $\begin{array}{l}\text { Ormanlar, meralar, bayırlar, } \\
\text { kayalık yamaçlar, akarsular, } \\
50-2400 \text { m (ibuflora, 2021). }\end{array}$ & $\begin{array}{l}\text { Çok yıllık } \\
\text { otsu bitki }\end{array}$ & $15-50 \mathrm{~cm}$ & $\begin{array}{l}\text { Mayıs- } \\
\text { Temmuz }\end{array}$ & $\begin{array}{l}\text { Leylak nadiren } \\
\text { beyaz renkli } \\
\text { çiçekler }\end{array}$ \\
\hline 9 & Geranium tuberosum & $\begin{array}{l}\text { Taşlı, kayalık yamaçlar, makilik, } \\
\text { açık alanlar (Çelik, Çiçek, Semiz ve } \\
\text { Karıncalı, 2003) }\end{array}$ & Yumrulu & $15-50 \mathrm{~cm}$ & $\begin{array}{l}\text { Nisan- } \\
\text { Haziran }\end{array}$ & $\begin{array}{l}\text { Mor- lila renkli } \\
\text { çiçek }\end{array}$ \\
\hline 10 & Cotoneaster nummularia & $\begin{array}{l}\text { Kalkerli kayalık yamaçlar, gölgeli } \\
\text { kıyılar, step, çalılık ve ağaçlıklar } \\
\text { (Eminağaoğlu, Yılmaz, Aksoy, Ok, } \\
\text { Fırat, Akyıldırım Beğen ve } \\
\text { Akkemik, 2020) }\end{array}$ & Çalı & $1-2,5 \mathrm{~m}$ & $\begin{array}{l}\text { Nisan- } \\
\text { Haziran }\end{array}$ & $\begin{array}{l}\text { Beyaz çiçek, kırmızı } \\
\text { meyve }\end{array}$ \\
\hline 11 & $\begin{array}{l}\text { Crataegus monogyna } \\
\text { var. monogyna }\end{array}$ & $\begin{array}{l}\text { Kireç taşı kayalıkları, maki, yamaç } \\
\text { araziler, meşe çalılığı ve karışık } \\
\text { ormanlar, 0-1800 m yükseklikler } \\
\text { (Özkan, Aslan ve Fırat, 2014) }\end{array}$ & $\begin{array}{l}\text { Çalı veya } \\
\text { küçük ağaç }\end{array}$ & $\begin{array}{l}10 \text { m}^{\prime} \text { ye } \\
\text { kadar }\end{array}$ & $\begin{array}{l}\text { Nisan- } \\
\text { Haziran }\end{array}$ & $\begin{array}{l}\text { Beyaz ya da } \\
\text { pembemsi çiçek, } \\
\text { kırmızı meyve }\end{array}$ \\
\hline 12 & $\begin{array}{l}\text { Prunus divaricata var. } \\
\text { divaricata }\end{array}$ & $\begin{array}{l}\text { Orman açıklıkları, bozkır yamaçları } \\
\text { ve kayalıklar arası (Akkemik ve } \\
\text { Eminağaoğlu, 2014). }\end{array}$ & $\begin{array}{l}\text { Çalı veya } \\
\text { küçük ağaç } \\
\text { (Mamıkoğlu, } \\
\text { 2007) }\end{array}$ & $\begin{array}{l}10 \text { m'ye }^{\prime} \\
\text { kadar }\end{array}$ & Nisan- Mayıs & $\begin{array}{l}\text { Beyaz çiçek, sarı } \\
\text { veya kırmızımsı } \\
\text { meyve }\end{array}$ \\
\hline 13 & Prunus spinosa & $\begin{array}{l}\text { Deniz seviyesinden } 1700 \mathrm{~m} \text { ye } \\
\text { kadar orman açıklıkları, orman } \\
\text { kenarı ya da açık alanlar (Akkemik } \\
\text { ve Eminağaoğlu, 2014). }\end{array}$ & Çalı & $\begin{array}{l}3 \text { m'ye } \\
\text { kadar }\end{array}$ & Mart- Nisan & $\begin{array}{l}\text { Yapraklanmadan } \\
\text { önce açan beyaz } \\
\text { çiçekler, mavimsi } \\
\text { siyahımsı dumanlı } \\
\text { meyve }\end{array}$ \\
\hline 14 & Lonicera caucasica & $\begin{array}{l}\text { Çalılık ve ormanlık alanlar } \\
\text { (TÜBiVES, 2021). }\end{array}$ & Çalı & $1-3 m$ & $\begin{array}{l}\text { Mayıs- } \\
\text { Temmuz }\end{array}$ & $\begin{array}{l}\text { Pembe veya beyaz } \\
\text { kokulu çiçek } \\
\text { (Eminağaoğlu, } \\
\text { Yüksel ve Aksu, } \\
\text { 2014) }\end{array}$ \\
\hline 15 & Thymus leucostomus & $\begin{array}{l}\text { Step, kayalık yamaçlar (Çıngay, } \\
\text { Ataşlar ve Koyuncu, 2017) }\end{array}$ & $\begin{array}{l}\text { Çok yıllık } \\
\text { otsu }\end{array}$ & $5-15 \mathrm{~cm}$ & $\begin{array}{l}\text { Mayıs- } \\
\text { Temmuz }\end{array}$ & $\begin{array}{l}\text { Beyaz çiçek, } \\
\text { aromatik yapraklar } \\
\text { ve koku }\end{array}$ \\
\hline 16 & Thymus sipyleus & $\begin{array}{l}\text { Dağ bozkırları, kayalık yamaçlar } \\
\text { (Çıngay, Ataşlar ve Koyuncu, 2017) }\end{array}$ & $\begin{array}{l}\text { Çok yıllık } \\
\text { ) otsu }\end{array}$ & $5-15 \mathrm{~cm}$ & $\begin{array}{l}\text { Mayıs- } \\
\text { Ağustos }\end{array}$ & $\begin{array}{l}\text { Beyaz çiçek, } \\
\text { aromatik yapraklar } \\
\text { ve koku }\end{array}$ \\
\hline
\end{tabular}

\section{Tartışma ve Sonuç}

Kentleşme, küresel ısınma ve diğer antropojenik etkiler, biyoçeşitliliği olumsuz yönde etkileyerek, bitki ve hayvan türlerinin popülasyonlarında azalmalara neden olmaktadır. Bitki türlerinin yok olması ya da azalması, üzerinde barınma ve beslenme imkânı sunduğu diğer canlıların yaşamını olumsuz yönde etkilemektedir. Özellikle polinatör böceklerin çeşitliliği ve yoğunluğundaki azalma, bitki çeşitliliği ve yoğunluğundaki azalmayı da beraberinde getirmektedir.

Literatür araştırmaları sırasında tozlaşma konusundaki Türkçe kaynakların daha çok polinatör böceklerin aktivitesi, tozlaşma sorunu, özellikle meyve, sebze ve yem bitkileri gibi bazı bitki türlerinin döllenme biyolojisi ve bu bitkileri ziyaret eden tozlaştırıcı canlılara yönelik olduğu görülmüştür.

Kentsel biyoçeşitlilik, kentsel alanlarda biyoçeşitliliğin geliştirilmesi ve korunması konusunu ele alan pek çok çalışma mevcuttur. Ancak bu çalışmalar arasında, biyoçeşitliliğin desteklenmesine yönelik 
olarak tozlaşmayı ve tozlaşmaya yardımcı bitkilerin kentsel peyzajlarda kullanımını ele alan Türkçe kaynakların sayısı sınırıdır. Bu konuda Özdemir ve Ulus (2018)' un, İstanbul şartlarında doğal olarak yetişen türler arasından yurt dışında tozlaşma bahçelerinde yoğun olarak kullanılan bitki türlerinin tespit edilmesine yönelik olarak yaptıkları bir çalışma mevcuttur. Bu çalışmada tozlaşma bahçelerinin tesisinde dikkat edilmesi gereken unsurlar da ayrıca ele alınmıştır.

Öztürk, Erkan, Ölçücü, Çiriğ, Özok ve Öğün (2017)' ün 'Van Illi Peyzaj Bitkilerinin Arıcılık Açısından Değerlendirilmesi' başlıklı çalışmaları ise süs bitkileri ve tozlaşma konusunu birlikte ele alan bir çalışmadır. Bu çalışmada, Van ilindeki rekreasyon alanlarında peyzaj çalışmalarında kullanılan süs bitkilerinin arıcılık açısından bir değerlendirmesi yapılmıştır.

Yabancı literatürde ise kentlerde polinatör ziyaretlerini inceleyen, polinatör popülasyonunu artırma ve biyoçeşitlilk alanında yapılan pek çok çalışmanın olduğu söylenebilir. Özellikle yurt dışında tozlaşma bahçeleri adı altında, kentsel biyoçeşitliliği destekleyen çalışmalar da gerçekleştirilmektedir.

Lowenstein, Matteson ve Minor (2018), kentlerde bitki- tozlaşma arasındaki ilişkiyi inceleyerek, tozlayıcılar tarafından hangi bitki taksonlarının tercih edildiğini araştırmışlardır. 3 yıllık araştırma periyodu sonunda, yüksek çekici türler olarak betimledikleri 42 takson belirlemişlerdir. Kentlerde polinatör popülasyonunu artırmak için bu türlerin kullanımını önermişlerdir. Ayrıca çalışmada, genel olarak çok yıllık ve yerli bitkilerin, daha fazla tozlayıcı ziyareti aldığını, 57 taksonun çiçeklendiği halde tozlayıcılar tarafından ziyaret edilmediğini tespit etmişlerdir.

Benvenuti (2014), 'Wildflower green roofs for urban landscaping, ecological sustainability and biodiversity' (Kentsel peyzaj için kır çiçekli yeşil çatılar, ekolojik sürdürülebilirlik ve biyoçeşitlilik) isimli çalışmasında, kır çiçekleri ile tasarlanmış çatı bahçelerinin ekolojik sürdürülebilirlik ve biyoçeşitlilik üzerindeki etkilerini ele almış, kır çiçeklerinin kentsel biyoçeşitliliğin artırılmasında önemli bir araç olduğunu ifade etmiştir.

Fukase ve Simons (2016)'ın, 'Increased pollinator activity in urban gardens with more native flora' (Daha doğal bitki örtüsüne sahip kent bahçelerinde artan tozlayıcı aktivitesi) başlıklı çalışmalarında, yerli bitki türlerinin bulunduğu kentsel alanların, yerli olmayan bitki türlerinin bulunduğu alanlara nazaran, polinatörlere daha kesintisiz kaynaklar sağladığını ve çeşitli polinatörleri çekme etkisi bulunduğunu ifade etmişlerdir.

Mach ve Potter (2018), 'Quantifying bee assemblages and attractiveness of flowering woody landscape plants for urban pollinator conservation' (Kentsel tozlayıcıların korunması için çiçekli odunsu peyzaj bitkilerinin çekiciliğinin ve arı topluluklarının ölçülmesi) başlıklı çalışmalarında, 72 çiçekli odunsu bitki türünde arı ziyaretlerini ölçmüşlerdir. Araştırmacılar, kent peyzajlarının arı ve diğer polinatör böceklerin barınması için bir olanak olabileceğini ifade etmişlerdir.

Landis, Dumroese ve Horning (2014) ise doğal bitki türlerinin yetişkin kelebekler ve onların tırtıl larvaları için, beslenme ortamı oluşturduğunu ifade etmişlerdir.

Kentsel peyzajlarda polinatörleri çekerek tozlaşmaya yardımcı olan doğal bitki örtüsündeki bitki türlerine yer verilmesi, kentsel biyoçeşitliliği artırma konusunda fayda sağlayabilmektedir. Doğal bitki örtüsünün ekolojik koşullara uygunluğu ve dayanıklı türler oluşu, özellikle iklim değişikliğine yönelik olarak değişen koşullara diğer türlere nazaran daha çabuk ve kolay uyum sağlayabileceği anlamına gelebilir. Ancak kentsel peyzaj çalışmalarında genellikle yabancı yurtlu bitkiler tercih edilmektedir. Bunun nedenleri; doğal türlerin yeterince tanınmaması, üretim yöntemlerinin bilinmemesi ve üretiminin yapılmaması dolayısıyla, kişilerin fidanlıklardan bu bitkileri temin edememesi olarak sayılabilir.

Bu çalışma, özellikle kentlerde biyoçeşitliliği artırma/destekleme konusunda, tozlaşma bahçelerinde ya da diğer tasarımlarda kullanılabilecek, polinatörleri çeken, peyzaj tasarımlarında kullanılabilecek bazı bitkilerin belirlenmesine yönelik olarak yapılmıştır. Çalışma, Ankara kentsel alanındaki tozlaştırıcı popülasyonunu dengeleyerek, biyoçeşitliliğin desteklenmesi çalışmalarında tercih edilebilmesi mümkün olan bazı bitki türlerini ortaya koymuştur. Ancak belirlenen bu türlerin peyzaj 
çalışmalarında kullanılabilmesi için en hızlı ve etkin çoğaltma olanaklarının belirlenmesi ve sektöre kazandırılması gerekmektedir.

Üretim konusunda yaşanan problemler nedeniyle kullanılmak istenen bitkilerin çoğunun, doğadan doğrudan toplanması riski söz konusu olabilmekte, bu şekilde doğanın tahribatı ve türlerin tükenme tehlikesi ile karşı karşıya kalınabilmektedir. Bu bakımdan, ilgili kişilerin ve araştırmacıların, yapılan bu ve bu gibi çalışmalar ışığında, belirlenen türlere yönelik üretim çalışmalarına başlaması büyük önem arz etmektedir. Sadece bitkilerin belli amaçlarla kullanım potansiyellerinin ortaya konulması ile kalınmamalı, ülkemizin sahip olduğu zengin biyoçeşitlilik ve genetik kaynakların korunması konusunda önemli diğer adımlar da vakit kaybetmeden atılmalıdır. Özellikle endemik bitkilerin izlenmesi ve korunması konusunda çalışmalara ağırlık verilmelidir.

Çeşitli bitki türlerinin bir araya getirilmesi ile oluşturulan tasarımlar, farklı sayıda ve çeşitte hayvanı destekleyeceğinden, flora ve fauna arasındaki bağların iyi bilinmesi önemlidir. Biyoçeşitlilik alanında ekolog, biyolog, zoolog, peyzaj mimarı gibi ilgili disiplinler ortak çalışmalar yürütmelidir.

Bazı bitki türleri yenilebilir özelliktedir. Örneğin Geranium tuberosum (Çakmuz)'un yumruları yenilmektedir (Baser, 2010) ya da Thymus spp. türlerinin yapraklarından baharat olarak yararlanılabilmektedir. Prunus divaricata var. divaricata (Yunus eriği) ise meyveleri tüketilen bir bitkidir. Yunus eriği yüksek antioksidan içeriğe sahip olup, insan sağlığına yararlı bir besindir (Çömlekcioğlu, Kocabaş ve Aygan, 2020). Kentsel alanlarda kullanılan bitki türlerinin yenilme durumu ve ihtimali de göz önüne alındığında, bazı bitki türlerin yenmesi halinde zehirli olabileceği düşünülerek, zehirli bitki türlerinin belirlenmesi ve ne şekilde kullanılması gerektiğine dair çalışmaların da yürütülmesi yararlı olabilecektir.

Tarıkahya Hacıoğlu, Erik ve Mutlu (2011), Ankara il sınırları dâhilinde yapılan floristik araştırmaların çeşitli parametreler bakımından, yerleşim alanıyla kıyaslanarak doğal ve doğal olmayan alanların ne ölçüde benzerlik veya farklılık gösterdiğini araştırdıkları çalışmalarında, toplam takson sayısının yalnızca \%6'ık kısmının kent merkezinde olduğunu belirlemişlerdir. Şehre özgü bitkilerin toplamının bu denli küçük bir oranda oluşu, şehir florasının fazla özgün olmadığı yönünde değerlendirilebilir. Bu bağlamda, doğal bitki türlerinin Ankara kenti peyzaj düzenlemelerinde kullanımının yaygınlaştırılması ile şehir florasının daha özgün bir hal alması mümkün olabilecek, doğal ve doğal olmayan alanlar arasındaki büyük farklııklar nispeten azaltılabilecektir.

\section{Teşekkür ve Bilgi Notu}

Makalede, ulusal ve uluslararası araştırma ve yayın etiğine uyulmuştur. Çalışmada etik kurul izni gerekmemiştir.

\section{Kaynaklar}

Akça, M. O., Türkmen, F., Taşkın, M. B., Soba, M. R. ve Öztürk, H. S. (2015). Ankara Üniversitesi Kalecik Araştırma ve Uygulama Çiftliği topraklarının Verimlilik Durumlarının İncelenmesi, Toprak Bilimi ve Bitki Besleme Dergisi, 3(2): 54 - 63. Online ISSN: 2146-8141. Erişim adresi (01.02.2021): https://dergipark.org.tr/tr/pub/tbbbd/issue/22384/239645

Akkemik, A. ve Eminağaoğlu, Ö. (2014). Prunus L. Ü. Akkemik (Ed). Türkiye'nin Doğal-Egzotik Ağaç ve Çalıları II içinde (ss.369-373). Ankara: T.C. Orman ve Su İşleri Bakanlığı Orman Genel Müdürlüğü Yayınları. Erişim adresi https://www.researchgate.net/publication/321748190_Prunus_L_Erikler

(17.01.2021):

Bağçıvan, G. (2014). Bursa ve Çevresinde Yayılışı Olan Dianthus L. Taksonları Üzerinde Sistematik Araştırmalar (Yüksek Lisans Tezi). Erişim adresi (27.05.2021): https://acikerisim.uludag.edu.tr/bitstream/11452/8325/1/360446.pdf

Bağrıaçık, N. (2017). Polinatör Böcekler ve Küresel Tozlaşma Krizi. Iğdır Üniversitesi Fen Bilimleri Enstitüsü Dergisi, 7(4): 37-41. Online ISSN: 2536- 4618. Erişim adresi: https://dergipark.org.tr/tr/pub/jist/issue/34627/390567

Baser, H. C. (2010). Türkiye'nin Yenen Yabani Bitkileri. Bağ Bahçe, 29 (Mayıs-Haziran): 22-25. Erişim 
adresi

(25.02.2021):

https://www.researchgate.net/publication/291972029_Turkiye'nin_Yenen_Yabani_Bitkileri

Bennett, A. B. ve Lovell, S. (2019). Landscape and Local Site Variables Differentially Influence Pollinators and Pollination Services In Urban Agricultural Sites. PLOS ONE, 14(2): e0212034. Erişim adresi

https://journals.plos.org/plosone/article?id=10.1371/journal.pone.0212034

(10.02.2021):

Benvenuti, S. (2014). Wildflower green roofs for urban landscaping, ecological sustainability and biodiversity. Landscape and Urban Planning, 124: 151-161. Erişim adresi (28.05.2021): https://www.sciencedirect.com/science/article/abs/pii/S016920461400005X

Campolo, O., Zappala, L., Malacrino, A., Laudani, F. ve Palmeri, V. (2015). Bees visiting flowers of Thymus longicaulis (Lamiaceae), Plant Biosystems - An International Journal Dealing with all Aspects of Plant Biology, 150 (6): 1182-1188. DOI: 10.1080/11263504.2015.1009190. Erişim adresi (29.04.2021): https://www.tandfonline.com/doi/full/10.1080/11263504.2015.1009190

Coşkun Hepcan, Ç. (2019). Kentlerde İklim Değişikliği ile Mücadele Için Yeşil Altyapı Çözümleri (iklim Değişikliği Eğitim Modülleri Serisi 12) iklim Değişikliği Alanında Ortak Çabaların Desteklenmesi Projesi (iklimiN) web sitesinden erişildi: http://www.iklimin.org/moduller/kentmoduluyesilaltyapi.pdf

Çelik, A., Çiçek, M., Semiz, G. ve Karıncalı, M. (2003). Taxonomical and Ecological Investigations on Some Geophytes Growing Around Denizli Province (Turkey). Turkish Journal of Botany, 28 (2004): 205-211. Erişim adresi (27.05.2021): https://journals.tubitak.gov.tr/botany/issues/bot04-28-1-2/bot-28-1-2-21-0211-18.pdf

Çıngay, B. Ataşlar, E. ve Koyuncu, O. (2017). Flora of Eskişehir Yazılıkaya valley and its environs. Biological Diversity and Conservation, 10/3 (2017): 36-50. Erişim adresi (28.05.2021): https://www.researchgate.net/profile/BurcinCingay/publication/322252809_Flora_of_Eskisehi r_Yazilikaya_valley_and_its_environs/links/5a4e512baca272c88278a7a6/Flora-of-EskisehirYazilikaya-valley-and-its-environs.pdf

Çömlekçioğlu, N., Kocabaş, Y. Z. ve Aygan, A. (2020). Kahramanmaraş'tan Toplanan Prunus divaricata subsp. divaricata Ledeb. Meyvelerinin Biyokimyasal Özellikleri ve Antimikrobiyal Aktivitelerinin Belirlenmesi. Anadolu, 30 (1): 46-56. Online ISSN: 2667-6087. Erişim adresi (25.02.2021): https://dergipark.org.tr/tr/pub/anadolu/issue/53926/727202

Demir, A. (2009). Küresel İklim Değişikliğinin Biyolojik Çeşitlilik ve Ekosistem Kaynakları Üzerine Etkisi. Ankara Üniversitesi Çevrebilimleri Dergisi, 1(2): 37-54. Erişim adresi (26.04.2021): http://dergiler.ankara.edu.tr/dergiler/47/1155/13590.pdf

Demir, O. (2018). Sedum acre subsp. acre. Osman Demir kişisel fotoğraf arşivi. Erişim adresi (27.02.2021):

https://www.facebook.com/photo?fbid=10213613678869376\&set=gm.1238191126283550

Demir, O. (2019). Sedum album. Osman Demir kişisel fotoğraf arşivi. Erişim adresi (27.02.2021): https://www.facebook.com/photo?fbid=10219766478405519\&set=pcb.2346234442145874

Demirpolat, A. ve Kılıç, Ö. (2019). Genç (Bingöl-Merkez) ilıçesi ve Çevresi Florasında Arıcılık Açısından Önemli Bitkiler, Uluslararası Doğu Anadolu Fen Mühendislik ve Tasarım Dergisi, 1(2): 135-141. ISSN: 2667-8764. Erişim adresi (28.04.2021): https://dergipark.org.tr/en/download/articlefile/1191286

Deniz, B. ve Şirin, U. (2005). Samson Dağı Doğal Bitki Örtüsünün Otsu Karakterdeki Bazı Örneklerinden Peyzaj Mimarlığı Uygulamalarında Yararlanma Olanaklarının İrdelenmesi, ADÜ Ziraat Fakültesi Dergisi, 2(2): 5-12. Erişim adresi (18.01.2021): http://adudspace.adu.edu.tr:8080/jspui/bitstream/11607/2414/1/bdeniz.pdf

Doğar, C. (2019). Ankara Üniversitesi Çiftliklerinin Florası (Yüksek lisans tezi). Ankara Üniversitesi Fen Bilimleri Enstitüsü, Ankara Üniversitesi Akademik Arşiv Sisteminden erişildi. Erişim adresi 
(15.01.2021) : https://dspace.ankara.edu.tr/xmlui/handle/20.500.12575/68985

Eker, I.., Vural, M. ve Aslan, S. (2015). Ankara Ilii' nin Damarlı Bitki Çeşitliliği ve Korumada Öncelikli Taksonları, Bağbahçe Bilim Dergisi, 2(3): 57- 114. Online ISSN: 2148 4015. Erişim adresi (27.02.2021): https://dergipark.org.tr/tr/pub/bagbahce/issue/53948/727582

Eminağaoğlu, Ö., Yılmaz, H., Aksoy, N., Ok, T., Fırat, M., Akyıldırım Beğen, H. ve Akkemik, Ü. (2020). Rosaceae. Ü. Akkemik (ed). Türkiye'nin Bütün Ağaçları ve Çalıları içinde (ss. 965-1125). İstanbul: Türkiye İş Bankası Kültür Yayınları, İstanbul.

Eminağaoğlu, Ö., Yüksel, E. ve Aksu, G. (2014). Lonicera L. Ü. Akkemik (Ed). Türkiye'nin Doğal-Egzotik Ağaç ve Çalıları I. içinde (ss. 422-431). Ankara: T.C. Orman ve Su İşleri Bakanlığı Orman Genel Müdürlüğü Yayınları. Erişim adresi (15.01.2021): https://www.researchgate.net/publication/321748099_Lonicera_L_Hanimelleri

Environmental Interpretive Center. (2021, 24 Şubat). Erişim adresi: https://umdearborn.edu/casl/centers-institutes/environmental-interpretive-center/researchresources/sustainability-initiatives/pollinator-garden

Fukase, J. ve Simons, A. M. (2016). Increased Pollinator Activity in Urban Gardens with More Native Flora. Applied Ecology and Environmental Research, 14 (1):297-310. Online ISSN: 17850037. Erişim adresi (27.02.2021): https://www.researchgate.net/publication/292606515_Increased_pollinator_activity_in_urba n_gardens_with_more_native_flora

Garbuzov, M. ve Ratnieks, F. L. W. (2014). Listmania: The Strengths and Weaknesses of Lists of Garden Plants to Help Pollinators, BioScience, 64(11): 1019-1026. DOI:10.1093/biosci/biu150. Erişim adresi https://academic.oup.com/bioscience/article/64/11/1019/2754229?login=true

Gösterit, A. ve Gürel, F. (2005). Bombus terrestris (Hymenoptera: Apidae) Arılarının Yayılmasının Ekosistem Üzerine Etkileri, Uludag Bee Journal, 5(3): 115-121. Erişim adresi (15.01.2021): https://dergipark.org.tr/tr/pub/uluaricilik/issue/53637/162510

Grimshaw-Surette, H. (2020). The Effect of Green Roof Characteristics on Pollinator Communities (Yüksek Lisans Tezi). Erişim adresi (29.04.2021): https://library2.smu.ca/handle/01/29346

IUCN (International Union for Conservation of Nature). (2021, 26 Nisan). IUCN Red List version 20211. Erişim adresi: https://www.iucnredlist.org/statistics

Ibuflora. (2021, 18 Ocak). Erişim adresi: http://ibuflora.ibu.edu.tr/tur/geranium-pyrenaicum

Karaköse, M., Akbulut, S. ve Bayramoğlu, M.M. (2018). Espiye (Giresun) Orman Planlama Birimi'nin İstilacı Yabancı Türleri, Türkiye Ormancılık Dergisi, 19(2): 120-129. DOI: 10.18182/tjf.349894. Erişim adresi (26.04.2021): https://dergipark.org.tr/en/download/article-file/511029

Landis, T. D., Dumroese, R. K. ve Horning, M. E. (2014). Create a Pollinator Garden at Your Nursery: An Emphasis on Monarch Butterflies. United States Department of Agriculture Forest Service, 34 (1-2), 2-13. Erişim 20.04.2021: https://www.researchgate.net/publication/272682145_Create_a_pollinator_garden_at_your_ nursery_an_emphasis_on_monarch_butterflies

Lowenstein, D. M., Matteson, K. C. ve Minor, E. S. (2015). Diversity of Wild Bees Supports Pollination Services in An Urbanized Landscape, Oecologia, 179:811-821. DOI: 10.1007/s00442-015-3389$0 . \quad$ Erişim adresi (18.01.2021): https://www.researchgate.net/publication/280136020_Diversity_of_wild_bees_supports_polli nation_services_in_an_urbanized_landscape

Lowenstein, D. M., Matteson, K. C. ve Minor, E. S. (2018). Evaluating the dependence of urban pollinators on ornamental, non-native, and 'weedy' floral resources. Urban Ecosystems, 22: 293-302. Erişim adresi (20.05.2021): https://link.springer.com/article/10.1007/s11252-018- 
$0817-z$

Lowry, H., Lill, A. ve Wong, B. (2013). Behavioural Responses Of Wildlife to Urban Environments. Biological Reviews, 88: 537-549.

Mamıkoğlu, N. G. (2007). Türkiye'nin Ağaçları ve Çalıları, NTV Yayınları, 727s, İstanbul.

Mach, B. M. ve Potter, D. A. (2018). Quantifying bee assemblages and attractiveness of flowering woody landscape plants for urban pollinator conservation. PLOS ONE 13(12):1-18. Erişim adresi (25.05.2021): https://journals.plos.org/plosone/article?id=10.1371/journal.pone.0208428

Maclvor, J. S., Ruttan, A. ve Salehi, B. (2015). Exotics on exotics: Pollen analysis of urban bees visiting Sedum on a green roof, Urban Ecosyst, 18: 419-430. DOI: 10.1007/s11252-014-0408-6. Erişim adresi (29.04.2021): https://link.springer.com/content/pdf/10.1007/s11252-014-0408-6.pdf

Özbek, H. (2003). Türkiye'de Arılar ve Tozlaşma Sorunu, Uludağ Arıcılık Dergisi, 3(3): 41-44. Erişim adresi (27.04.2021): https://dergipark.org.tr/en/pub/uluaricilik/issue/53715/162696

Özbek, H. (2010). Arılar ve İnsektisitler. Uludağ Arıcılık Dergisi, 10(3): 85-95. Erişim adresi (15.01.2021): https://dergipark.org.tr/tr/pub/uluaricilik/issue/52019/162359

Özdemir, A. ve Ulus, A. (2018). Kent Ekolojisine Farklı Bir Yaklaşım: Tozlaşma Bahçeleri, Inonu University Journal of Art and Design, 8(18): 17-28. Online ISSN: 1309-9884. Erişim adresi (27.02.2021): https://dergipark.org.tr/tr/pub/iujad/issue/44357/491404

Özkan, N. G., Aslan, S. ve Fırat, M. (2014). Crataegus L. Ü. Akkemik, (Ed). Türkiye'nin Doğal-Egzotik Ağaç ve Çalıları I içinde (ss. 43-66). Ankara: T.C. Orman ve Su İşleri Bakanlığı Orman Genel Müdürlüğü Yayınları. Erişim https://www.researchgate.net/publication/274892998_Crataegus_L_Aliclar

Öztürk, F., Erkan, C., Ölçücü, C., Çiriğ, N., Özok, N. ve Öğün, E. (2017). Van Illi Peyzaj Bitkilerinin Arıcılık Açısından Değerlendirilmesi. Yüzüncü Yıl Üniversitesi Tarım Bilimleri Dergisi, 27 (4): 601-607. Erişim adresi (20.04.2021): https://dergipark.org.tr/tr/pub/yyutbd/issue/33357/316240

Polat, B., Özüiçli, M., Çetin, H. ve Aydın, L. (2020). Pestisit Kullanımının Bal Arısı Sağlığına ve Ürünlerine Etkisi, Journal of Research in Veterinary Medicine, 39(2): 128-134. DOI:10.30782/jrvm..634586. Erişim adresi (18.01.2021): https://dergipark.org.tr/tr/pub/jrvm/issue/59210/634586

Selim, C., Sever Mutlu, S. ve Selim, S. (2015). Kentsel Alanlarda Biyolojik Çeşitliliğin Sürdürülebilirliği ve Koruma Yaklaşımları. Türk Bilimsel Derlemeler Dergisi, 8(1): 38-45. Online ISSN: 1308-0040. Erişim adresi

(27.02.2021): http://www.derleme.gen.tr/index.php/derleme/article/download/267/265

Silici, S. (2005). Tozlaşmada Polen ve Nektar Cezbediciliğinin Önemi. Alatarım, 4(2): 57-61. ISSN: 1304- 2653. Erişim adresi (18.01.2021): https://arastirma.tarimorman.gov.tr/alata/Belgeler/alatarim/alatarim008_2005_12.pdf\#page= 60

Smithsonian Gardens. (2021, 24 Şubat). Erişim adresi: https://gardens.si.edu/gardens/pollinatorgarden/

Tarıkahya Hacıoğlu, B., Erik, S. ve Mutlu, B. (2011). Ankara Yerleşim Merkezinin, Çevresindeki Alanlarla Floristik Yönden Karşılaştırılması, Manisa Celal Bayar Üniversitesi Eğitim Fakültesi Dergisi, 1 (2): 60-77. ISSN:1309-8918. Erişim adresi (15.01.2021): https://www.researchgate.net/publication/282353574_Ankara_Yerlesim_Merkezinin_Cevresi ndeki_Alanlarla_Floristik_Yonden_Karsilastirilmasi

The Plant List. (2021, 27 Nisan) Erişim adresi: http://www.theplantlist.org/1.1/statistics/

TÜBiVES. (2021, 16 Ocak). Erişim adresi: http://www.tubives.com/

UN-Habitat (United Nations Human Settlements Programme). (2016). Urbanization and 
Development: Emerging Futures, World Cities Report 2016. Erişim adresi: https://unhabitat.org/sites/default/files/download-manager-files/WCR-2016-WEB.pdf

Uslu, A. ve Shakouri, N. (2013). Kentsel Peyzajda Yeşil Altyapı ve Biyolojik Çeşitliliği Destekleyecek Olanaklar, Türk Bilimsel Derlemeler Dergisi, 6(1): 46-50. Online ISSN: 2146-0132. Erişim adresi (27.02.2021): http://derleme.gen.tr/index.php/derleme/article/view/181/179

Varol, Ö. ve Aydoğdu, M. (1999). The Flora of Steppe Surrounding Akyurt and Kalecik (Ankara), Communications Faculty of Science University of Ankara Series C, 17: 33-57. DOI: 10.1501/Commuc_0000000093. Erişim adresi (15.01.2021): https://www.researchgate.net/publication/275576973_The_flora_of_steppe_surrounding_Ak yurt_and_Kalecik_Ankara

Wenzel, A., Grass, I., Vasuki V. B. ve Tscharntkea, T. (2019). How Urbanization is Driving Pollinator Diversity and Pollination - A systematic Review. Biological Conservation, 241(2020): 1-15. DOI: 10.1016/j.biocon.2019.108321. Erişim adresi (15.02.2021): https://www.sciencedirect.com/science/article/abs/pii/S0006320719307761\#: :text=A\%20tot al\%20of\%20141\%20studies

Yılmaz, T. (2008a). Cotoneaster nummularia. Turgut Yılmaz kişisel fotoğraf arşivi. Erişim adresi (27.02.2021):

https://www.facebook.com/photo?fbid=2772809946326987\&set=pcb.3102225856546725

Yılmaz, T. (2008b). Thymus leucostomus. Turgut Yılmaz kişisel fotoğraf arşivi. Erişim adresi (27.02.2021):

https://www.facebook.com/photo?fbid=2775904369350878\&set=pcb.3113132708789373

Yılmaz, T. (2008c). Prunus divaricata var. divaricata. Turgut Yılmaz kişisel fotoğraf arşivi. Erişim adresi (27.02.2021):

https://www.facebook.com/photo?fbid=2780600042214644\&set=pcb.3129172107185433

Yılmaz, T. (2011). Dianthus lydus. Turgut Yılmaz kişisel fotoğraf arşivi. Erişim adresi (27.02.2021): https://www.facebook.com/photo?fbid=2762629104011738\&set=pcb.3065710540198257

Yılmaz, T. (2019). Geranium tuberosum. Turgut Yılmaz kişisel fotoğraf arşivi. Erişim adresi (27.02.2021):

https://www.facebook.com/photo?fbid=2384517438489575\&set=basw.AbrB7HHMPyr-

Yılmaz, T. (2019). Thymus sipyleus. Turgut Yılmaz kişisel fotoğraf arşivi. Erişim adresi (27.02.2021): https://www.facebook.com/photo?fbid=2388022784805707\&set=pcb.1999669560135699 